the outer $\sim 60 \mathrm{~km}$ of the silicates. Even with complete serpentinization of this region, an $\mathrm{H}_{2} \mathrm{O}$ abundance consistent with Europa's density implies an outer water/ice layer many tens of kilometres thick.

If solid state convection could occur in the ice shell, heat transport rates would be sufficient to freeze the underlying water $^{18}$ rapidly. Using an ice activation energy constant of $E / k T_{\text {melting }}=26$ rather than the value of 18 used previously ${ }^{6}$, solid state convection could only occur for ice crusts thicker than about $30 \mathrm{~km}$, however. The larger value is favoured by Weertman $^{19}$, and is consistent with observations of crater relaxation on icy satellites ${ }^{20}$. Again taking a thermal conductivity appropriate for solid ice $\left(3.4 \times 10^{5} \mathrm{erg} \mathrm{cm}^{-1} \mathrm{~K}^{-1}\right)$, we expect a thin $(<30 \mathrm{~km})$ shell of ice underlain by liquid water to exist at present if the surface heat flow has never been lower than $\sim 20 \mathrm{erg} \mathrm{cm}^{-2} \mathrm{~s}^{-1}$.

These calculations are sensitive to parameter uncertainties, particularly because the heat flux is comparable in magnitude with that required to maintain a liquid layer. Our parameter estimates are consistent with the presence of such a layer. For confirmation we must look to the observational evidence.

The paucity of craters on Europa implies a mean retention time for $10 \mathrm{~km}$ craters of only $3 \times 10^{7} \mathrm{yr}$ based on an impact flux calculated from the expected collision rate with comet nuclei ${ }^{21}$. Using appropriate relationships for relaxation of topography with temperature dependent viscosity ${ }^{22}$ and a geothermal gradient given by our calculated heat flow, and making the very conservative assumption that a crater will become 'invisible' once its floor rebounds by a factor of $1 / e$, this retention time implies a surface viscosity corresponding to a temperature of $\sim 140 \mathrm{~K}$. This value is much higher than the mean solar equilibrium temperature of $\sim 92 \mathrm{~K}$, and actually must be higher still to relax crater rims. To allow high nearsurface temperatures, even for very high heat flows, an insulating blanket at the surface is required. Fracturing of a thin ice crust over liquid water could provide such a blanket. Water exposed by fracturing would not flood the surface, due to the buoyancy of the crust, but would boil, producing vapour that would condense as frost over a large area. Frosts typically have very low densities and thermal conductivities, and could provide the insulation required. An insulating layer could also result in an average crustal thickness much less than the mean value of $\sim 16 \mathrm{~km}$ calculated for conduction in solid ice alone.

There is evidence for such a frost layer. First, the photometric function of Europa requires much more homogeneous scattering than produced by ejecta deposits of equal albedo on Ganymede and Callisto ${ }^{4}$. The difference is probably textural, and is consistent with a more tenuous structure than produced by impacts. Second, deposits of sulphur, evidenced by a UV absorption feature ${ }^{3}$, are only present on the trailing hemisphere. This feature is attributed to $\mathrm{S}-\mathrm{O}$ bonds, and a sulphur column density of $2 \times 10^{16} \mathrm{~cm}^{-2}$ is inferred. Estimated values for the flux of $\mathrm{S}$ ions into Europa's trailing hemisphere predict that this column density would be deposited in only $\sim 7 \mathrm{yr}$. These observations were interpreted to require equilibrium between deposition of $\mathrm{S}$ ions and escape of $\mathrm{SO}_{2}$ molecules by charged particle sputtering, since $\mathrm{H}_{2} \mathrm{O}$ escapes more readily than $\mathrm{SO}_{2}$ (ref. 23). Recent measurements ${ }^{24}$ have shown that $\mathrm{SO}_{2}$, which is more volatile than $\mathrm{H}_{2} \mathrm{O}$ at thermal energies, is more easily sputtered than $\mathrm{H}_{2} \mathrm{O}$ by high-energy particles. As $\mathrm{SO}_{2}$ also has a lower escape rate, such a model would imply higher abundances on the leading hemisphere where sputtering is much less severe, contrary to observations. Assuming instead that the observed column density is a result of uniform addition of $S$ ions to a surface on which a much larger amount of $\mathrm{H}_{2} \mathrm{O}$ is continually deposited, an estimate of the minimum $\mathrm{H}_{2} \mathrm{O}$ deposition rate can be obtained. For a UV measurement depth of $5,000 \AA$, this rate would be $\sim 0.1 \mu \mathrm{m} \mathrm{yr}^{-1}$.

The appearance of Europa is consistent with this model. Vapour released from fractures will travel large distances, while particulate matter such as salts or organic material would be preferentially deposited near an open active surface. Such material could also undergo radiation darkening ${ }^{25}$, creating a pattern of darker features on a bright surface. Stresses sufficient to fracture the crust could be generated by tidal flexure ${ }^{6,26}$, or by membrane stresses induced by rotation of the ice shell over Europa's tidal bulge. The crust would in reality be inhomogeneous in thickness, and fractures would form preferentially in thinner regions. Continuing or repeated deformation would cause repetitive activation of pre-existing fractures. If large resurfacing events are frequent on Europa they might be observable as transient increases in the thermal IR flux or as clouds of vapour and condensate visible to the Galileo orbiter.

We thank A. Eviatar and D. L. Matson for helpful discussions and corrections to the manuscript.

Received 26 July; accepted 5 Novemher 1982.

1. Smith, B. A. Science 206, 927-950 (1979).

2. Pilcher, C. B., Ridgway, T. B. \& McCord, T. B. Science 178, 1087-1089 (1972).

3. Lane, A. L., Nelson, R. M. \& Matson, D. L. Nature 292, 38-39 (1981).

. Buratti, B. \& Veverka, J. Icarus (submitted).

5. Consolmagno, G. J. \& Lewis, J. S. in Jupiter (ed. Gehrels, T.) (University of Arizona Press, Tueson, 1976)

6. Cassen, P. M., Reynolds, R. T. \& Peale, S. J. Geophys. Res. Lett. 6, 731-734 (1979)

7. Cassen, P. M., Peale, S. J. \& Reynolds, R. T. Geophys. Res. Lett. 7, 987-988 (1980)

8. Ransford, G. A. Finnerty, A. A \& Collerson, K. D. Nature 289, 21-24 (1981)

Cassen, P. M., Peale, S. J. \& Reynolds, R. T. in The Satellites of Jupiter (ed. Morrison, D.) (University of Arizona Press, Tucson, 1982)

10. Yoder, C. F. Phil. Trans. R. Soc. Lond. 303, 327-338 (1981)

11. Cappallo, R. J., Counselman, C. C., King, R. W. \& Shapiro, I. I. J. geophys. Res. 86, 7180-7184 (1981)

12. Matson, D. L., Ransford, G. A. \& Johnson, T. V. J. geophys. Res. 86, 1664-1672 (1980)

13. Sinton, W. M. J. geophys. Res. 86, 3122-3128 (1980).

14. Morrison, D. \& Telesco, C. in The Satellites of Jupiter (ed. Morrison, D.) (University of Arizona Press, Tucson, 1982)

15. Bullen, K. E. The Earth's Density (Halsted, New York, 1981).

15. Bullen, K. E. The Earth's Density (Halsted, New York,

17. Rayleigh, C. B. \& Paterson, M. S. J. geophys. Res. 70, 3965-3985 (1965).

18. Reynolds, R. T. \& Cassen, P. M. Geophys. Res. Lett. 6, 121-124 (1979)

19. Weertman, J, in Physics and Chemistry of Ice (eds Whalley, E., Jones, S. J. \& Gold, L. W. (Royal Society of Canada, 1973).

20. Passey, Q. R. \& Shoemaker, E. M. J. geophys. Res. (submitted)

21. Shoemaker, E. M. \& Wolfe, R. F. in The Satellites of Jupiter (ed. Morrison, D.) (University of Arizona Press, Tucson, 1982).

22. Parmentier, E. M. \& Head, J. W. Icarus 47, 100-111 (1981)

23. Eviatar, A., Siscoe, G. L., Johnson, T. V. \& Matson, D. L. Icarus 47, 75-83 (1981).

24. Lanzerotti, L. J., Brown, W. L., Johnson, R. E. \& Armstrong, T. P. Astrophys. J. 259 920-929 (1982)

25. Fanale, F. P., Johnson, T. V. \& Matson, D. L. in Planetary Satellites (ed. Burns, J. A.) (University of Arizona Press, Tucson, 1977)

26. Helfenstein, P. \& Parmentier, E. M. Lunar planet. Sci. Conf. XI, 1987-1998 (1980)

\section{Metamorphic fluids in the deep crust: evidence from the Adirondacks}

\author{
J. W. Valley*, James McLelland $\dagger$, E. J. Essene $\ddagger$ \\ \& William Lamb* \\ * Department of Geology, Rice University, Houston, \\ Texas 77251, USA \\ $\uparrow$ Department of Geology, Colgate University, Hamilton, \\ New York 13346, USA \\ $\ddagger$ Department of Geological Sciences, University of Michigan, \\ Ann Arbor, Michigan 48109, USA
}

Unusual mineral assemblages of tremolitic hornblende + diopside + enstatite + quartz have been examined to estimate the temperature $(T)$ and water fugacity $\left(f_{\mathrm{H}_{2} \mathrm{O}}\right)$ at the time of the granulite facies metamorphism in the Adirondacks. The pyroxenes are closely represented by the system $\mathrm{CaO}-\mathrm{MgO}$ $\mathrm{SiO}_{2}$ allowing application of experimental data ${ }^{1}$ with only small corrections for reduced values of activities. Tremolite equilibria ${ }^{2}$ buffered $\log f_{\mathrm{H}_{2} \mathrm{O}}=3.0 \pm 0.1$, equivalent to $0.9 \mathrm{kbar}$ of water pressure $\left(\boldsymbol{P}_{\mathrm{H}_{2} \mathrm{O}}\right)$ at $7 \mathrm{kbar}, 710^{\circ} \mathrm{C}$. Nearby marbles contain wollastonite + calcite + quartz and buffered $P_{\mathrm{CO}_{2}}=1.1 \mathrm{kbar}$, consistent with $\boldsymbol{P}_{\mathrm{H}_{2} \mathrm{O}} \leqslant 5.9 \mathrm{kbar}$. Inferred local gradients in fluid compositions suggest that deep crustal fluid conditions are complex and heterogeneous indicating that fluid movements, whether of mantle ${ }^{3}$ or deep crustal origin, are channelized rather than pervasive. Thus some granulite facies rocks were wholly or partly closed systems with respect to externally derived fluids permitting localized buffering of fluid compositions. Recognition of restricted fluid-mixing limits theories that call for massive amounts of pervasive fluid flow to facilitate melting, cause metasomatism, or to stabilize granulite facies mineralogy. 


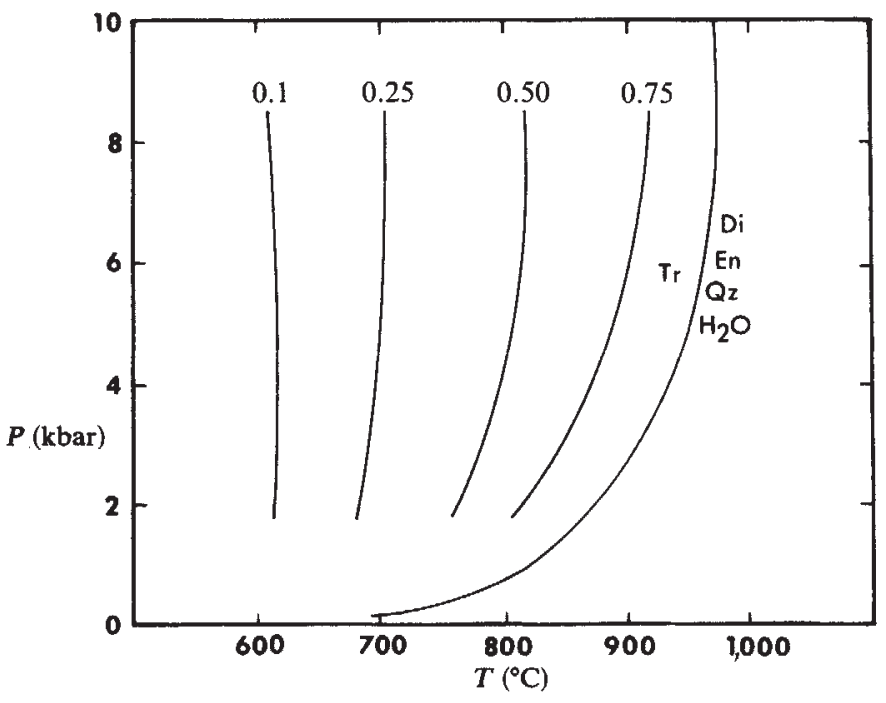

Fig. 1 Dehydration equilibria for synthetic tremolite ${ }^{2}$ for $X_{\mathrm{H}_{2} \mathrm{O}}=0.1,0.25,0.50,0.75$ and 1.0 .

We have found a series of metasediments containing enstatite and diopside located at Wolf Hill (JM/TRD) and Burnham Mountain (ST14) in the south-east Indian Lake Quadrangle in the Adirondack Mountains, New York, USA. These localities are $2-4 \mathrm{~km}$ from the contact of the Oregon Dome, a major anorthosite outlier of the Mt Marcy anorthosite massif ${ }^{4}$. Detailed mapping and structural analysis show the upper contact of the Oregon Dome to dip shallowly beneath these metasediments ${ }^{4}$, suggesting the possibility of early contact metamorphism. While this may have occurred, the equilibria now preserved are consistent with $P-T$ conditions at the peak of regional metamorphism during the $1,000-\mathrm{Myr}$ Grenville orogeny. Any contact aureole that formed during intrusion of the anorthosite has thus been overprinted by the subsequent granulite facies metamorphism. This is supported by textural relationships, showing undeformed, poikiloblastic grains of enstatite and diopside growing across well-defined planes of foliation. This foliation is regional and occurs throughout the nearby anorthosite ${ }^{4}$; which, therefore, predates the assemblages under consideration. This conclusion is consistent with radiometric dates that suggest anorthosite intrusion some 100 200 Myr before regional metamorphism ${ }^{5,6}$.

The $P-T$ conditions of granulite facies metamorphism in the Adirondacks are well known from several studies. Isotherms have been contoured using temperature estimates from reintegrated feldspar and oxide compositions?. These temperatures are in good agreement with those estimated from silicate reactions ${ }^{8,9}$. Pressures have been estimated from the common occurrences of sillimanite ${ }^{10}$ and rare kyanite ${ }^{11,12}$, from ferrosilite and fayalite-quartz assemblages ${ }^{13}$, from a rock containing akermanite-monticellite-wollastonite ${ }^{9}$, and from various garnet assemblages ${ }^{14,15}$. Taken together, these data from differing rock types and widely spaced localities are selfconsistent and indicate that $T=710 \pm 30^{\circ} \mathrm{C}$ and $P=7 \pm 1 \mathrm{kbar}$ for the peak of regional metamorphism in south-east Indian Lake Quadrangle.

Minerals were analysed by electron microprobe using standatd procedures for analysis, data reduction and cation normalization $^{8}$. Representative analyses are given in Table 2 . The pyroxenes are remarkably close to the diopside-enstatite join with $1-2 \% \mathrm{Al}_{2} \mathrm{O}_{3}$ as their greatest impurity. Enstatites contain 92-97 $\mathrm{mol}_{\%} \mathrm{MgSiO}_{3}$ and diopsides contain 88-94 mol \% $\mathrm{CaMgSi}_{2} \mathrm{O}_{6}$. Phlogopites are slightly peraluminous with 13.1 wt $\% \mathrm{Al}_{2} \mathrm{O}_{3}$. Approximate whole-rock chemical analyses (Table 2) were calculated from modes (Table 1), the mineral analyses and estimated densities.

The solvus between enstatite and diopside has been experimentally reversed at various $P-T$ (ref. 1 ), but none of the experimental data is greatly restrictive below $15 \mathrm{kbar}$ and
Table 1 Mineralogy and modal analysis (1,000 points)

\begin{tabular}{lcc}
\hline & JM/TRD-2 & ST-14-1 \\
Quartz & 56.8 & 3.4 \\
Diopside & 11.2 & 54.5 \\
Enstatite & 1.0 & 21.8 \\
Amphibole & 31.0 & - \\
Phlogopite & - & 14.1 \\
Pyrrhotite & - & 2.6 \\
Apatite & - & 0.1 \\
Plagioclase & - & 3.5 \\
\hline
\end{tabular}

$850^{\circ} \mathrm{C}$. Margules formulations have been fit to the pyroxene data with a maximum discrepancy of $18{ }^{\circ} \mathrm{C}$ between model and experiment ${ }^{16}$. Application of these equations to the pyroxene pairs, using the Wood-Banno model ${ }^{17}$ for distributing minor cations, yields $T=278-625^{\circ} \mathrm{C}$ (Table 3 ). In this temperature range the solvus is steep and very sensitive to small analytical, experimental or thermodynamic errors. Routine errors in microprobe analysis alone could account for the discrepancy between these values and the inferred metamorphic $T$ suggesting that the pyroxene solvus, as applied here, is not precise enough to be useful for metamorphic thermometry. Alternatively, it could be proposed that these temperatures accurately represent retrograde reequilibration of pyroxenes, but our data do not resolve this.

The calculated rock analyses (Table 2) are unusual with high $\mathrm{Mg}, \mathrm{Mg}>\mathrm{Ca}$, low $\mathrm{Fe}$ and variable Si. Talc-tremolite-quartz schists near Balmat in the north-west Adirondacks have similar chemistry and are associated with halite and anhydrite-bearing marbles that are clearly metaevaporites ${ }^{18}$. The samples of this study may thus represent isochemical metamorphism of evaporites or they may have been metasomatized, possibly by nearby anorthosite.

Many reactions can be written for the dehydration of a complex natural amphibole to a pyroxene-bearing assemblage. The simplest end-member reaction that has been experimentally calibrated ${ }^{2}$ is:

tremolite $=$ diopside + enstatite + quartz $+\mathrm{H}_{2} \mathrm{O}$

Our sample, JM/TRD, contains this $\mathrm{H}_{2} \mathrm{O}$-buffering assemblage. Figure 1 shows this reaction calculated for various values of $X_{\mathrm{H}_{2} \mathrm{O}}$. Reaction positions were calculated from the equilibrium point at $P_{\mathrm{H}_{2} \mathrm{O}}=2 \mathrm{kbar}, T=875^{\circ} \mathrm{C}$ (ref. 2) using the computer program EQUILI ${ }^{8}$. To apply reaction (1) to the assemblage of JM/TRD a correction must be made for the effects of solid solution in both the amphibole and pyroxenes. In the absence of calibrated activity versus composition relations this correction can be approximated using an ideal ionic model ${ }^{8,17}$. This results in a change of Gibbs energy of reaction (1) of -4.8 to $-6.8 \mathrm{~kJ}$ due primarily to fluortremolite and tschermakite solid solution in amphibole. The range of energies derives from different amphibole models with variable order-disorder on various cation sites and extends the stability of amphibole $75-100^{\circ} \mathrm{C}$, consistent with experiments on tschermakite ${ }^{19}$. At $7 \mathrm{kbar}, 710^{\circ} \mathrm{C}$ these compositions thus buffer $X_{\mathrm{H}_{2} \mathrm{O}}=0.11-0.14$ or $\log f_{\mathrm{H}_{2} \mathrm{O}}=3.0 \pm 0.1$ (Fig. 1). A larger uncertainty in the application of these experiments arises from results showing that some synthetic tremolites decompose more than $100^{\circ} \mathrm{C}$ below natural tremolite, possibly due to crystal defects accounting for up to $8 \mathrm{~kJ}$ change in Gibbs energy ${ }^{20}$. In extreme cases, a correction for the effect of crystal defects in the experimental charge would shift estimated $X_{\mathrm{H}_{2} \mathrm{O}}$ from 0.11 to 0.05 while high contact metamorphic temperatures of $850^{\circ} \mathrm{C}$ would shift estimated $\boldsymbol{X}_{\mathrm{H}_{2} \mathrm{O}}$ from 0.11 to 0.29 . Low $\boldsymbol{P}_{\mathrm{H}_{2} \mathrm{O}}$ is indicated in any case.

Considerable controversy exists as to the significance of low $\boldsymbol{P}_{\mathrm{H}_{2} \mathrm{O}}$ values in high grade metamorphic rocks. It has been proposed that low $P_{\mathrm{H}_{2} \mathrm{O}}$ results from dilution of a fluid phase by deep-seated $\mathrm{CO}_{2}$ (refs 3,21) or $\mathrm{CH}_{4}$ (ref. 22) of either crustal or mantle origin or that alternatively there was no free fluid phase ${ }^{23}$. A traditional alternative view regards 
Table 2 Electron microprobe analyses of minerals and calculated rock analyses

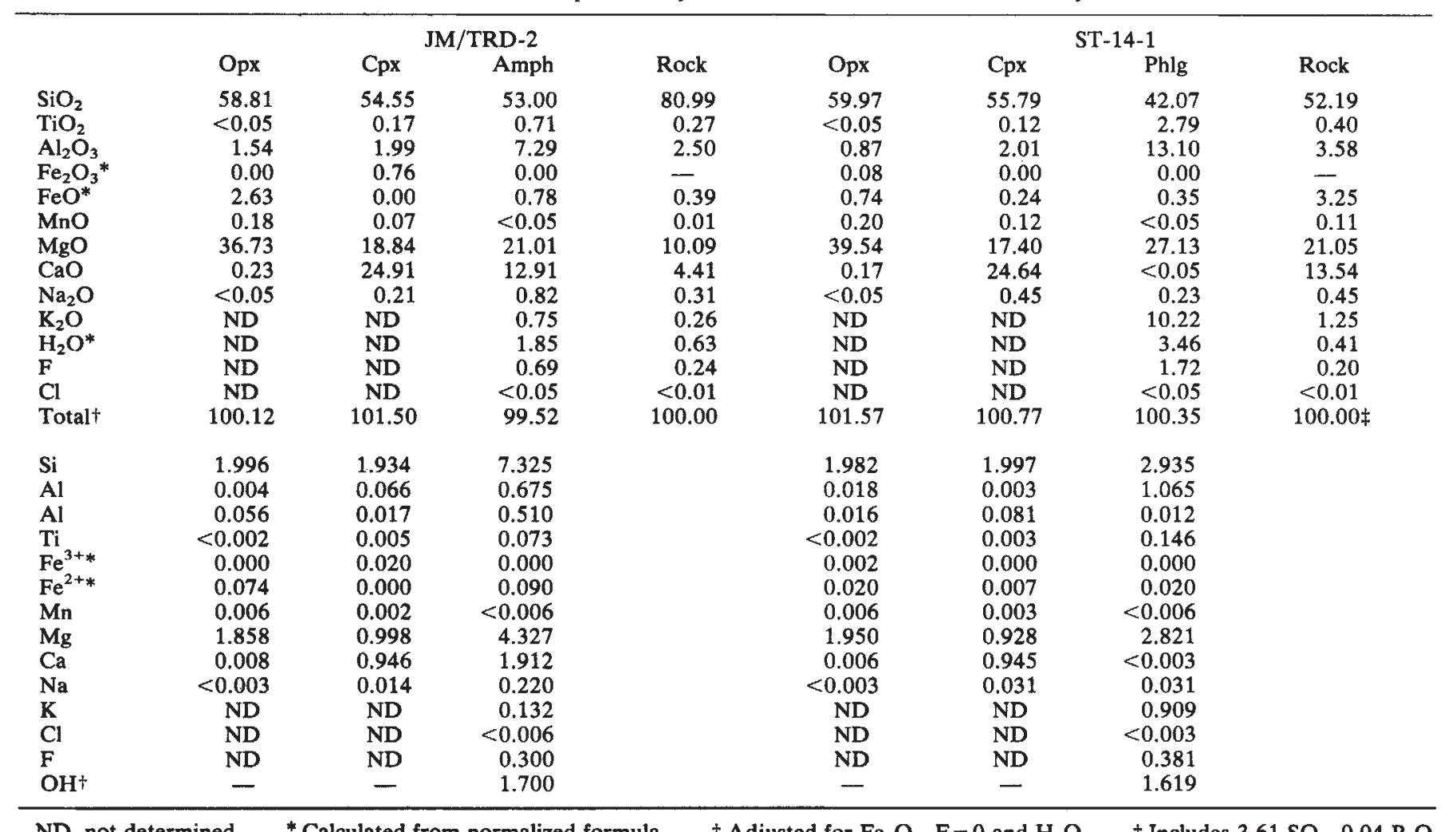

ND, not determined.

* Calculated from normalized formula.

$\dagger$ Adjusted for $\mathrm{Fe}_{2} \mathrm{O}_{3}, \mathrm{~F}=0$ and $\mathrm{H}_{2} \mathrm{O} . \quad \ddagger$ Includes $3.61 \mathrm{SO}_{3}, 0.04 \mathrm{P}_{3} \mathrm{O}_{5}$.

Table 3 Calculated activities of $\mathrm{MgMgSi}_{2} \mathrm{O}_{6}$ and $\mathrm{CaMgSi}_{2} \mathrm{O}_{6}$ in pyroxenes and calculated equilibrium $T \dagger$

\begin{tabular}{lcc}
\hline & JM/TRD & ST-14 \\
${ }^{*} \alpha_{\mathrm{MgMgSi}_{2} \mathrm{O}_{6}}^{\mathrm{opx}}$ & 0.863 & 0.951 \\
${ }^{*} \alpha{ }_{\mathrm{CaMgSi}}^{\mathrm{ppx}} \mathrm{O}_{6}$ & 0.007 & 0.006 \\
${ }^{*} \alpha_{\mathrm{MgMgSi}}^{\mathrm{cpx} \mathrm{O}_{6}}$ & 0.037 & 0.018 \\
${ }^{*} \alpha_{\mathrm{CaMgSi}}^{\mathrm{cpx}}$ & 0.907 & 0.860 \\
$+T_{\mathrm{A}}\left({ }^{\circ} \mathrm{C}\right)$ & 451 & 278 \\
$+T_{\mathrm{B}}\left({ }^{\circ} \mathrm{C}\right)$ & 557 & 625 \\
\hline
\end{tabular}

* From ref. 17.

$\dagger$ Using equations $\mathrm{A}$ and $\mathrm{B}$ of ref. 16.

low $\boldsymbol{P}_{\mathrm{H}_{2} \mathrm{O}}$ values as anomalous and assumes that in general $\boldsymbol{P}_{\mathrm{H}_{2} \mathrm{O}}=\boldsymbol{P}_{\text {lithostatic. }}$

The samples of this study occur in proximity to granulite facies, wollastonite-bearing marbles that buffered metamorphic fluids to low $P_{\mathrm{CO}_{2}}$. Sample SP202-1 was also collected from Burnham Mountain, $1 \mathrm{~km}$ on strike from ST-14 and contains the assemblage wollastonite + calcite + quartz + grossular + sphene + apatite ${ }^{8}$. Grossular $\left(\mathrm{Gr}_{88}\right)+$ quartz in this sample limits temperature to below $815^{\circ} \mathrm{C}$ at $7 \mathrm{kbar}$ (ref. 9), further arguing against high temperature contact metamorphism. The assemblage wollastonite + calcite + quartz buffers $P_{\mathrm{CO}_{2}}$ to 1.1 kbar. Similar low values of $P_{\mathrm{CO}_{2}}$ are inferred for 30 other wollastonite localities that are known in the Adirondacks including the mines near Willsboro, New York that account for most of the world wollastonite production ${ }^{8,9,12,24}$.

If the fluids of granulite facies metamorphism are pervasive and migrate in sufficient quantity to control buffering reactions ${ }^{3,21}$, then the fluid compositions inferred in marbles should be similar to those in the nearby two-pyroxene rocks. This would indicate that both $\boldsymbol{P}_{\mathrm{H}_{2} \mathrm{O}}$ and $\boldsymbol{P}_{\mathrm{CO}_{2}}$ were low during Adirondack metamorphism requiring large quantities of some other fluid diluent in the lower crust. Alternatively, we believe that $\boldsymbol{P}_{\mathrm{H}_{2} \mathrm{O}}$ and $\boldsymbol{P}_{\mathrm{CO}_{2}}$ can be highly variable in marbles and sharp gradients in fluid composition can exist ${ }^{8}$. Such a model suggests great complexity in fluid compositions of the deep crust that is not generally recognized. Locally high $P_{\mathrm{H}_{2} \mathrm{O}}$ and low $P_{\mathrm{CO}_{2}}$ in marbles can stabilize wollastonite while nearby rocks might have low $P_{\mathrm{H}_{2} \mathrm{O}}$ stabilizing the two-pyroxene assemblages reported here. Recognition of complex fluid conditions would indicate that generalities should be made with caution as to the composition of fluids in the granulite facies. Such fluid movement as exists in the deep crust may largely be channelized and restricted to zones of weakness, structural misfit or permeable lithologies.

Received 9 August; accepted 18 November 1982

1. Lindsley, D. H. \& Dixon, S. A. Am. J. Sci. 276, 1285 (1976).

2. Boyd, F. R. in Researches in Geochemistry (ed. Abelson, P. H.) 377 (Wiley, New York, 1959).

3. Newton, R. C., Smith, J. V. \& Windley, B. Nature 288, 45 (1980).

4. McLelland, J. \& Isachsen, Y. Bull. geol. Soc. Am. 81, 68, 208 (1980).

5. Silver, L. T. N.Y. State Mus. Sci. Serv. Mem. 18, 233 (1969)

6. Ashwal, L. D., Wooden, J. L. \& Shih, C. Y. Geol. Soc. Am. Abstr. Prog. 12, 380 (1980).

7. Bohlen, S. R., Essene, E. J. \& Hoffman, K. Bull. geol. Soc. Am. 91, 110 (1980)

8. Valley, J. W. \& Essene, E. J. Bull. geol. Soc. Am. 91, 114, 720 (1980).

9. Valley, J. W. \& Essene, E. J. Contr. Miner. Petrol. 74, 143 (1980).

10. Essene, E. J., Bohlen, S. R. \& Valley, J. W. Geol. Soc. Am. Abstr. Prog. 9, 260 (1977)

11. Boone, G. M. Geol. Soc. Am. Abstr. Prog, 10, 34 (1978).

12. Weiner, R. W., McLelland, J. M., Isachsen, Y. W. \& Hall, L. M. Bull. geol Soc. Am. in the press).

13. Bohlen, S. R. \& Boettcher, A. L. Am. Miner. 66, 951-964 (1981).

14. Johnson, C. A., Essene, E. J. \& Bohlen, S. R. Geol. Soc. Am. Abstr. Prog. 11, 451 (1979).

15. Bohlen, S. R., Boettcher, A. L. \& Wall, V. J. Geol. Soc. Am. Abstr. Prog. 13, 412 (1981).

15. Bohlen, S. R., Boettcher, A. L. \& Wall, V. J. Geol. Soc. Am. Abstr. Prog. 13, 412 (1981),
16. Lindsley, D. H. Grover, J. E. \& Davidson, P. M. in Thermodynamics of Minerals and Lindsley, D. H., Grover, J. E. \& Davidson, P. M. in Thermodynamics of Minerals and
Melts (eds Newton, R. C., Navrotsky, A. \& Wood, B. J.) 149 (Springer, Berlin, 1981). 17. Wood, B. J. \& Banno, S. Contr. Miner. Petrol. 42, 109 (1973).

18. Brown, J. S. \& Engel, A. E. J. Bull. geol, Soc. Am. 67, 1599 (1956).

19. Oba, T. J. Fac. Sci. Hokkaido Univ. Ser. IV 18, 339 (1978)

20. McKinstry, B. \& Skippen, G. Geol. Soc. Am. Abstr. Prog. 10, 454 (1978).

21. Glassicy, W. Nature 295, 229 (1982).

22. Soter, S. \& Gold, T. Scient. Am. 243, 154 (1980).

23. Essene, E. J., Bohlen, S. R. \& Valley, J. W. Geol. Soc. Am. Abstr. Prog. 10, 397 (1978). 24. Valley, J. W. \& O'Neil, J. R. Nature 300, 497-500 (1982). 